\title{
Differential positive control by Oct-1 and Oct-2: activation of a transcriptionally silent motif through Oct-1 and VP16 corecruitment
}

\author{
Michele A. Cleary, ${ }^{1,2}$ Seth Stern, ${ }^{1,3}$ Masafumi Tanaka, ${ }^{1}$ and Winship Herr ${ }^{1}$ \\ ${ }^{1}$ Cold Spring Harbor Laboratory, Cold Spring Harbor, New York 11724 USA; ${ }^{2}$ Department of Molecular Microbiology, \\ State University of New York at Stony Brook, Stony Brook, New York 11794 USA
}

Transcriptional regulation by the ubiquitous human POU homeo domain protein Oct-1 and the related B-cell protein Oct- 2 is a model for understanding how proteins that recognize the same regulatory site elicit different programs of gene transcription. Here, we describe a mechanism for differential promoter activation whereby only Oct-1, through selective corecruitment with the herpesvirus trans-activator VP16, acquires the ability to stimulate transcription from a TAATGARAT-containing site that responds to neither Oct-1 nor Oct-2 alone. To measure differential in vivo activation by human Oct-1 and Oct-2 in response to VP16, we have developed a transient assay in murine NIH-3T3 cells. Surprisingly, murine Oct-1 associates with VP16 much less effectively than its human counterpart, most likely because the murine Oct-1 homeo domain differs at four positions from the human Oct-1 homeo domain. The murine cell transient assay shows directly that human Oct-1, but not human Oct-2, can respond to VP16 in vivo. The Oct-1 DNA-binding POU domain is sufficient and the Oct-1 homeo domain is critical for this response, because an Oct-1 POU domain containing the Oct-2 homeo domain fails to respond to the VP16-induced positive control of transcription. Thus, by selective homeo domain interaction and corecruitment to an otherwise silent regulatory element, VP16 expands the repertoire of sites responsive to Oct-1 without affecting the activity of its close relative Oct-2.

[Key Words: Homeo domain; POU domain; herpesvirus; cooperative DNA binding; murine Oct-1]

Received October 9, 1992; revised version accepted November 16, 1992.

A perplexity of eukaryotic transcriptional regulation is the ability of proteins with the same inherent DNAbinding specificity to direct distinct patterns of gene expression. This apparent paradox has been underscored by studies of Drosophila development, where numerous homeo domain proteins with highly similar DNA-binding properties participate in unique programs of transcriptional regulation. In many cases, the homeo domain itself confers the specificity of transcriptional regulation by mechanisms that are poorly understood (see Hayashi and Scott 1990).

The mammalian POU homeo domain proteins Oct-1 and Oct- 2 serve as models for resolving these mechanisms. Via their homeo domain-containing POU domains, both proteins recognize the same DNA sequences, including the octamer motif ATGCAAAT (Staudt et al. 1986; Clerc et al. 1988; Sturm et al. 1988; Aurora and Herr 1992). One mechanism by which they can differentially regulate gene expression is through promoter-selective activation domains, which stimulate

${ }^{3}$ Present address: University of Massachusetts Medical Center, Program in Molecular Medicine, Worcester, Massachusetts 01613 USA. transcription from specific octamer motif-containing promoters (Tanaka et al. 1988; Tanaka et al. 1992). Previous in vivo studies have demonstrated that, by this mechanism, Oct-1 activates the human U2 small nuclear RNA (snRNA) promoter more effectively than Oct-2 does (Tanaka et al. 1992), and Oct-2 activates the human $\beta$-globin promoter, an mRNA-type promoter, more effectively than Oct-1 does (Tanaka and Herr 1990; Kemler et al. 1991). Oct-1, however, appears to acquire Oct-2-like mRNA promoter activation properties by association with the herpes simplex virus (HSV) trans-activator VP16 (also called Vmw65 and $\alpha$ TIF), which contains a potent acidic mRNA-type promoter activation domain (for review, see Goding and O'Hare 1989; Herr 1992; Thompson and McKnight 1992).

During a lytic infection, the virion protein VP16 initiates a developmental program of HSV gene expression by associating with Oct-1 in a multiprotein-DNA complex. Efficient formation of this VP16-induced complex depends on a second, less well-characterized, host cell factor called HCF (also called Cl, CCF, and VCAF) (Gerster and Roeder 1988; Kristie et al. 1989; Katan et al. 1990; Xiao and Capone 1990; Stern and Herr 1991) and is 
directed by the cis-regulatory target of VP16, the TAATGARAT ( $R=$ purine) motif (McKnight et al. 1987; O'Hare and Goding 1988; Preston et al. 1988). Two forms of the TAATGARAT element exist in the promoters of the HSV immediate early genes. One form, referred to here as OCTA $^{+} \mid$TAATGARAT, is characterized by an overlapping octamer motif, which binds Oct-1 and Oct-2 (Gerster and Roeder 1988; O'Hare and Goding 1988). The second form of the TAATGARAT motif, called (OCTA ${ }^{-}$)TAATGARAT, lacks an overlapping octamer motif. On such a site, Oct-1 and Oct- 2 recognize the TAATGARAT motif as a degenerate octamer sequence and bind with weak affinity (Baumruker et al. 1988; apRhys et al. 1989; Aurora and Herr 1992).

Unlike Oct-1, Oct-2 does not associate effectively with VP16 (Gerster and Roeder 1988). This differential interaction does not depend on the presence of HCF (Stern and Herr 1991; Pomerantz et al. 1992) and results from amino acid differences on the surfaces of the Oct-1 and Oct-2 homeo domains that are thought to be accessible for protein contacts when the homeo domains are bound to DNA (Stern et al. 1989; Lai et al. 1992; Pomerantz et al. 1992). Thus, the selective association of VP16 with Oct-1 demonstrates how a regulatory cofactor can discriminate between homeo domains, even those bound to the same DNA site.

Although VP16 associates selectively with Oct-1, the mRNA promoter activation properties of Oct-1 and Oct-2 in the presence or absence of VP16 have been analyzed on an octamer motif-containing cis-regulatory site that is active in the presence of either Oct- 2 or a combination of Oct-1 and VP16 (Tanaka et al. 1988). Thus, in this case, the selective association of Oct-1 with VP16 does not result in the activation of different promoters by Oct- 1 and Oct-2.

We show here that, in our assays, an $\left(\mathrm{OCTA}^{-}\right)$ TAATGARAT element does not respond effectively to either Oct-1 or Oct- 2 in the absence of VP16. Oct-1, however, acquires new and distinctive properties not shared with Oct- 2 by activating transcription on this site in the presence of VP16. The response to Oct-1 correlates with the ability of VP16 and Oct-1 to recruit each other to this type of TAATGARAT element. This selective corecruitment reveals a second mechanism whereby proteins with the same inherent DNA-binding specificity can direct distinct patterns of gene expression, in this case through discriminating protein interaction with the DNA-binding domain.

\section{Results}

To compare the activities of Oct- 1 and Oct- 2 on the low-affinity (OCTA-) TAATGARAT site, we used an (OCTA ${ }^{-}$)TAATGARAT site from the bidirectional HSV IE3 (ICP4) and IE4/5 immediate early promoter characterized previously by Preston and colleagues (Preston et al. 1988). As a positive control for Oct-1 and Oct-2 activity, we measured the activity of an octamer motif originating from the human histone H2B promoter. Fig- ure $1 \mathrm{~A}$ shows the sequence of the two sites, along with double point mutations used to inactivate each site. As indicated in Figure 1A by the underlying broken bracket, the H2B octamer motif resembles an OCTA $^{+}$|TAATGARAT site because of a 6- of 9-base match to the TAATGARAT sequence; consistent with this sequence similarity, this octamer motif, together with a critical $\mathrm{C}$ residue provided by the $X$ hoI linker sequence $(\underline{C} T C$; boxed in Fig. 1A), binds to VP16 (see below) and responds to VP16 in vivo (data not shown).

To measure transcriptional activity of the wild-type and mutant octamer and (OCTA ${ }^{-}$|TAATGARAT sites in response to Oct-1 and Oct-2 in transient expression assays, we designed the reporter plasmid illustrated in Figure 1B. The plasmid contains two divergently ori-

A
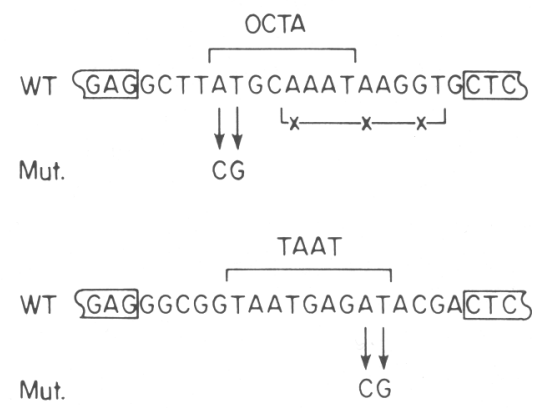

B

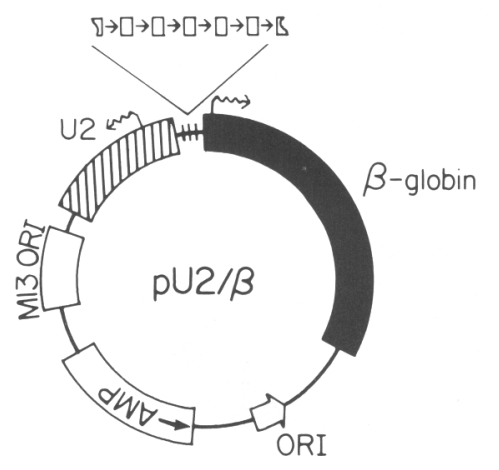

Figure 1. (A) Wild-type and mutant sequences of the octamer (top) and (OCTA-)TAATGARAT (bottom) elements used in this study. Brackets above each sequence define the location of each motif, and boxed residues represent $X h o I$ recognition sequences used to separate the individual sites in the six tandem copy constructs. Vertical arrows beneath each wild-type sequence (WT) indicate mutated bases within the mutant forms of each site (Mut.). A bracket marking a sequence overlapping the octamer motif highlights similarity to a TAATGARAT motif (a 6- of 9-base match) with $\mathrm{X}^{\prime}$ s designating the differences. $(B) \mathrm{A}$ schematic representation of the $\mathrm{pU} 2 / \beta$ reporter plasmid used for the in vivo studies. The pUC1 19-based plasmid contains two transcription units, U2 (hatched) and $\beta$-globin (solid), driven by divergent promoters oriented as indicated by the wavy arrows. Small rectangles and arrows illustrate the array of six tandem sequence elements generated for each cis-regulatory site and inserted between the two promoters. 
ented reporter genes, one driven by the Oct-1-responsive U2 snRNA promoter and the other driven by the Oct-2responsive $\beta$-globin mRNA promoter. To test the transcriptional response of each site, we generated synthetic enhancers comprised of six tandem copies of each wildtype and mutant site and inserted each synthetic enhancer individually between the two promoters. This double-promoter construct allowed us not only to measure U2 snRNA and $\beta$-globin mRNA promoter activation in different cell types but also to evaluate their responsiveness to VP16. To assay promoter activity, we measured levels of mRNA synthesis by RNase protection and compared these levels to those from a cotransfected internal reference plasmid containing the human $\alpha$-globin transcription unit.

Oct-1 and Oct-2 fail to activate the (OCTA ${ }^{-}$) TAATGARAT element in the absence of VP16

Figure 2 shows the response of the U2 snRNA and the $\beta$-globin mRNA promoters in HeLa cells, which contain Oct- 1 , to the octamer and (OCTA ${ }^{-}$)TAATGARAT sites along with the response of the $\beta$-globin mRNA promoter in murine NS-1 B cells, which contain both Oct-1 and Oct-2. As positive and negative controls for activation of both promoters in both cell types, we used wild-type (octa $^{+} \mathrm{sph}^{+}$) and mutant $\left(\right.$octa $\left.^{-} \mathrm{sph}^{-}\right)$copies of a bipartite SV40 enhancer element containing an octamer motif overlapping tandem 9-bp sph motifs. The octamer motif can activate the U2 snRNA promoter in HeLa cells and

A

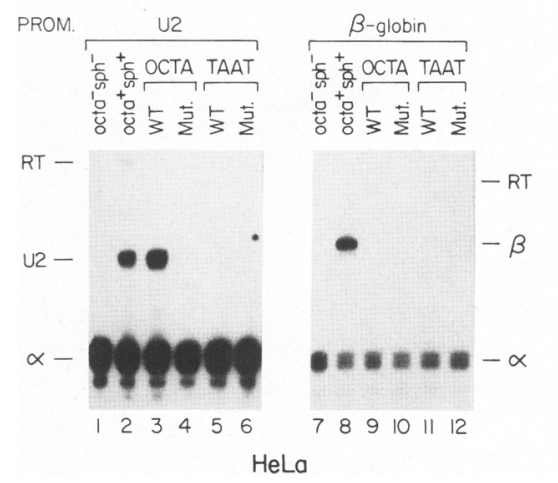

Figure 2. The HSV (OCTA ${ }^{-}$/TAATGARAT element fails to activate octamer-responsive promoters in the absence of VP16. (A) Expression from the U2 and $\beta$-globin promoter constructs in HeLa cells. The octa ${ }^{-} \mathrm{sph}^{-}($lanes 1,7$)$ and octa ${ }^{+} \mathrm{sph}^{+}($lanes 2,8$)$ sites served as negative and positive activation controls, respectively. The activity of both promoters with the wild-type (lanes 3,9 ) and mutant (lanes 4,10) H2B octamer site, and the wild-type (lanes 5,11) and mutant (lanes 6,12) (OCTA ${ }^{-}$)TAATGARAT site is shown. (PROM.) Promoter activity assayed; (RT) readthrough transcripts; (U2) correctly initiated U2 promoterdriven transcripts; $(\beta)$ correctly initiated $\beta$-globin promoterdriven transcripts; $\{\alpha \mid$ internal human $\alpha$-globin control. $(B)$ An analogous assay to that described in $A$, except NS-1 B cells were used and only $\beta$-globin RNA was measured. All lanes and abbreviations are as described in $A$. the $U 2$ and $\beta$-globin promoters in B cells, whereas the tandem sph motifs can activate the $\beta$-globin promoter in HeLa cells (Tanaka et al. 1988). By virtue of the combined activities of these motifs, the wild-type element is active in each assay (Fig. 2A, lanes 2,8; Fig. 2B, lane 2), whereas the mutant version is inactive (Fig. 2A, lanes 1,7; Fig. 2B, lane 1).

In HeLa cells (Fig. 2A), although the wild-type (U2; lane 3) but not mutant (lane 4) octamer sequence effectively activates the U2 snRNA promoter, the wild-type and mutant $/ \mathrm{OCTA}^{-}$|TAATGARAT sequences fail to do so (lanes 5,6$)$. Consistent with the inability of a wildtype octamer motif to activate the minimal $\beta$-globin promoter effectively in HeLa cells (Tanaka et al. 1988), when the same samples probed for U2 snRNA promoter activity in lanes 1-6 were probed for $\beta$-globin mRNA transcripts as shown in lanes 7-12, neither the octamer nor the (OCTA ${ }^{-}$)TAATGARAT element activated transcription $(\beta$; lanes 9,11$)$. In contrast, in the B-cell line (Fig. 2B), the $\beta$-globin promoter responds to tandem copies of the wild-type (lane 3) but not mutant (lane 4) octamer motif but, as in the case of the $\mathrm{U} 2$ promoter in HeLa cells, fails to respond to the wild-type and mutant (OCTA ${ }^{-}$|TAATGARAT site (lanes 5,6). This result was also obtained in two human B cell lines, Namalwa and BJA-B (data not shown), but their transfection efficiencies were greatly reduced from that of the murine NS-1 cell line described above.

Thus, in two instances-the U2 snRNA promoter in HeLa cells and the $\beta$-globin mRNA promoter in B cellsthe OCCTA $^{-}$|TAATGARAT site fails to activate an octamer motif-responsive promoter. This unequivocal result provides the basis for the mode of differential regulation of gene expression by Oct- 1 and Oct- 2 described here, because this (OCTA $^{-}$ITAATGARAT element is known to activate an mRNA-type promoter in response to VP16 in vivo (Preston et al. 1988; see also Triezenberg et al. 1988b), and VP16 is known to associate effectively with Oct-1 but not Oct-2 in vitro (Gerster and Roeder 1988; Kristie et al. 1989; Stern et al. 1989). We present evidence below that by selective corecruitment Oct-1 and VP16 can uniquely activate transcription from the low-affinity (OCTA $^{-}$)TAATGARAT site.

\section{The (OCTA-)TAATGARAT element can activate} both the $\beta$-globin and U2 promoters in the presence of VP16

Figure 3 shows that the (OCTA $^{-}$/TAATGARAT element can activate both the $\beta$-globin mRNA and the U2 snRNA promoters in the presence of VP16. Activation of mRNA promoters by VP16 depends on a potent carboxyterminal acidic activation domain of VP16 (Triezenberg et al. 1988a; Greaves and O'Hare 1989). We used our double-promoter reporter constructs to assay the mRNA and snRNA promoter responses of the (OCTA $^{-}$/TAATGARAT site to VP16 and two mutant forms of VP16: One lacks the carboxy-terminal activation domain $(\Delta \mathrm{C})$, and the other both lacks the carboxy-terminal domain and contains a 4-amino-acid insertion (in 14; also referred 


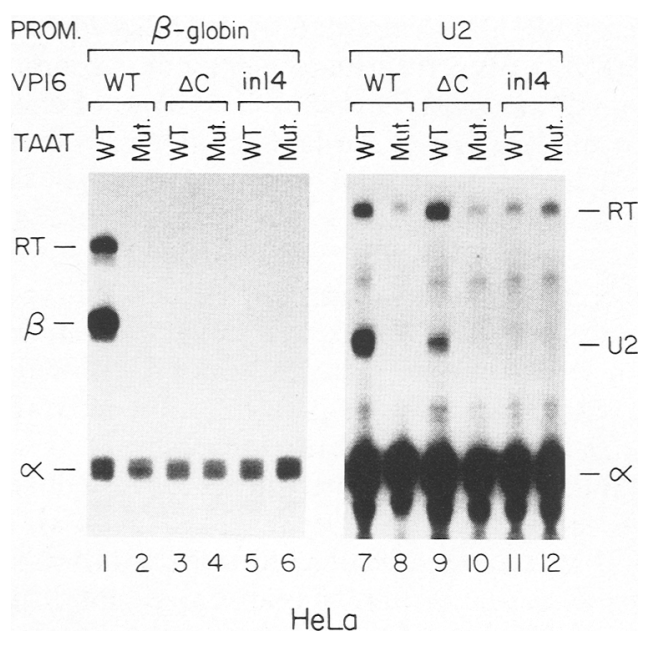

Figure 3. The HSV (OCTA ${ }^{-}$)TAATGARAT site activates $\beta$-globin mRNA and U2 snRNA gene transcription in the presence of VP16. The response of wild-type [(WT) lanes 1,3,5,7,9, 11] and mutant [(Mut.) lanes 2,4,6,8,10,12] (OCTA ${ }^{-}$)TAATGARAT (TAAT) sites was assayed in the presence of wild-type VP16 [(WT) lanes $1,2,7,8]$ and VP16 mutants $\Delta \mathrm{C}$ (lanes $3,4,9,10$ ) and $\Delta \mathrm{C}$-in 14 (lanes $5,6,11,12$ ) for $\beta$-globin mRNA $($ left $)$ and U2 snRNA (right) gene transcription. Other abbreviations are as in Fig. 2. The same RNA samples were used to probe for $\beta$-globin and U2 RNA (data not shown).

to as RIIi in Stern and Herr 1991), which prevents VP16 association with Oct-1 (Ace et al. 1988; Stern and Herr 1991). Immunoblot analysis revealed that wild-type VP16 was expressed in transient assays at a lower level than the two mutant forms, which were expressed at similar levels.

As shown in Figure 3, in the presence of wild-type VP16, the otherwise silent (OCTA ${ }^{-}$)TAATGARAT site can readily activate not only the $\beta$-globin promoter (lane 1) but also the U2 snRNA promoter (lane 7) in HeLa cells. Activation of both promoters is disrupted by the double point mutation in the (OCTA ${ }^{-}$|TAATGARAT site (lanes 2,8$)$ and by the combined $\Delta \mathrm{C}$ and in 14 mutation in VP16 (lanes 5,11 ). Consistent with previous results, activation of the $\beta$-globin promoter is also lost when the carboxy-terminal activation domain of VP16 is removed (lane 3).

Because the U2 snRNA promoter does not respond to the yeast acidic activator GAL4 (Tanaka et al. 1988) nor to a fusion protein containing the GAL4 DNA-binding domain and the carboxy-terminal acidic VP16 activation domain (G. Das and W. Herr, unpubl.), the VP16 activation domain is not expected to play a role in activation of the U2 promoter. Consistent with this hypothesis, the U2 promoter with the wild-type (lane 9), but not the mutant (lane 10) (OCTA ${ }^{-}$|TAATGARAT element still responds to VP16 $\mathrm{C}$, albeit three- to fourfold less effectively, despite the absence of the carboxy-terminal activation domain. Therefore, it is likely that VP16 does not provide an activation domain but, instead activates the U2 promoter by inducing complex formation with Oct-1 on the (OCTA ${ }^{-}$|TAATGARAT element and thus allowing the snRNA activation domains in Oct- 1 to activate transcription of this promoter. We do not know the reasons for the reduced efficiency with which the U2 promoter is activated by the carboxy-terminally truncated VP16 protein, but it may be the result of its higher level of expression or an alteration of the protein structure.

\section{Oct-1 but not Oct-2 is corecruited with VP16 to the $\left(\mathrm{OCTA}^{-}\right)$TAATGARAT element}

There are two nonmutually exclusive models that can explain how VP16 activates the U2 promoter from the OOCTA $^{-}$|TAATGARAT element by inducing complex formation with Oct-1. The first model posits that Oct-1 is bound to the (OCTA ${ }^{-}$|TAATGARAT site in vivo but is not in a functional state unless also bound to VP16. The second model postulates that in the absence but not in the presence of VP16, the Oct-1 occupancy of the (OCTA $^{-}$|TAATGARAT site in vivo is not high enough to stimulate transcription well. Consistent with the model that VP16 increases the occupancy of Oct-1 on the OOCTA $^{-}$|TAATGARAT site, in an electrophoretic mobility retardation assay using HeLa nuclear extract, the (OCTA ${ }^{-}$TAATGARAT site can form more Oct-1-containing VP16-induced complex in the presence of VP16 than the complex containing only Oct-1 in the absence of VP16 (Preston et al. 1988). To extend this observation, we used more defined components and a DNase I protection assay to measure the effects of VP16 on occupancy of the (OCTA ${ }^{-}$|TAATGARAT site by Oct-1 and Oct-2 in solution.

We used the DNA probe illustrated in Figure 4 (bottom) to assay the ability of Oct-1 or Oct- 2 to bind simultaneously to the $\mathrm{H} 2 \mathrm{~B}$ octamer and (OCTA $^{-}$|TAATGARAT sites in the presence and absence of VP16. The octamer site serves as a positive control not only for Oct-1 and Oct- 2 binding on their own but also for their binding in association with VP16, because it resembles an (OCTA ${ }^{+}$|TAATGARAT site (see Fig. 1A), on which VP16 extends the Oct-1 protection pattern (Kristie et al. 1989). We expressed and purified from Escherichia coli the Oct-1 and Oct-2 POU domains as well as a protein A-VP16 fusion protein (Werstuck and Capone 1989b). HCF was provided by a partially purified HeLa cell-derived fraction devoid of Oct-1 activity.

As shown in Figure 4A (lanes 1,2), we first adjusted the concentration of Oct-1 such that protection of the (OCTA $^{-}$) TAATGARAT site is just detectable. At this concentration, the higher affinity octamer site is fully protected. At higher concentrations of Oct-1 ( $\geqslant 8$-fold), the partially protected residues at the $\left(\mathrm{OCTA}^{-}\right.$)TAATGARAT site in lane 2 are completely protected (data not shown). Alone, the concentration of VP16 used in this assay has no effect on either site (cf. lanes 1 and 6), and the HCF-containing fraction has no effect on either the Oct-1 (cf. lanes 2 and 3) or VP16 (lanes 5 and 6) protection patterns. In contrast, the combination of all three factors, Oct-1, VP16, and HCF, extends the protection on the octamer site and induces a nearly complete protec- 


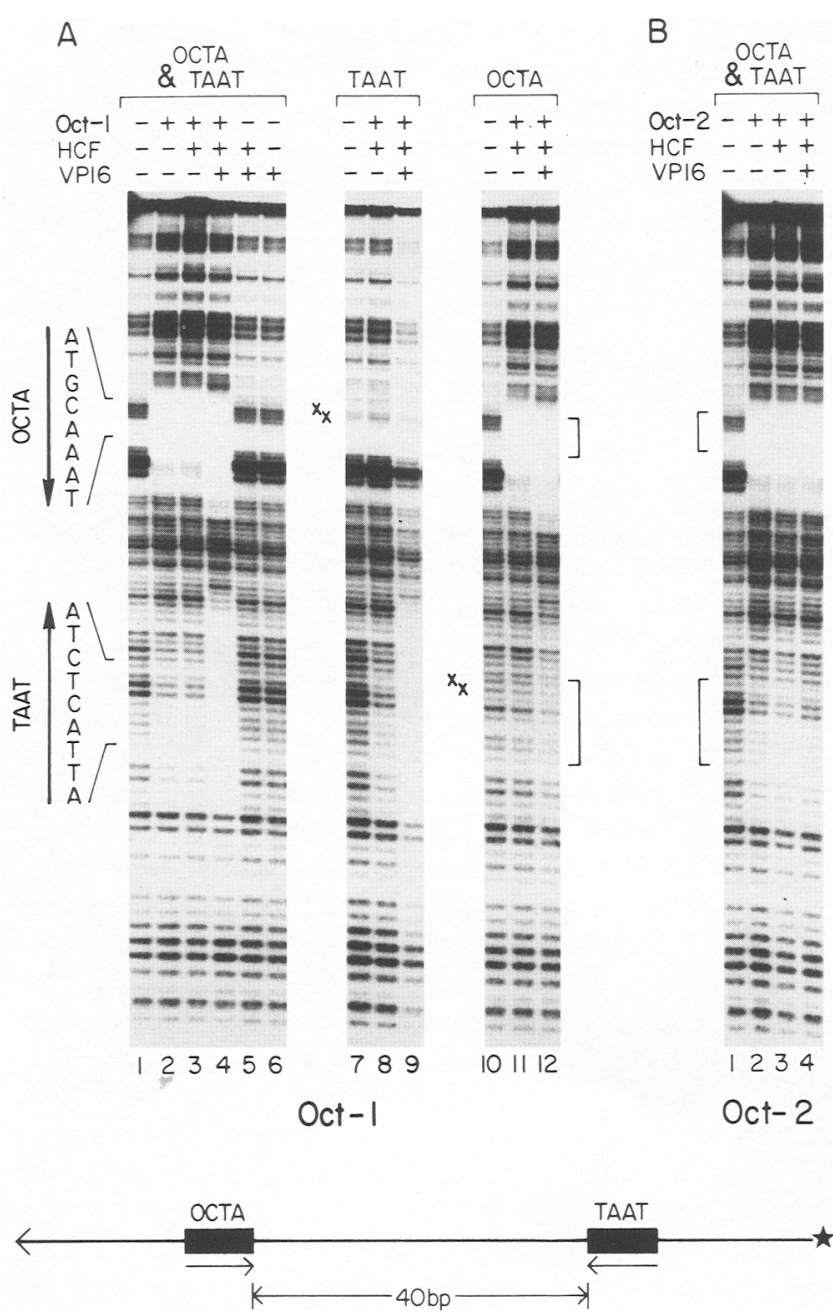

Figure 4. Oct-1 but not Oct- 2 is corecruited with VP16 to the (OCTA - TTAATGARAT element. A probe (bottom) containing the (OCTA ${ }^{-}$|TAATGARAT motif (TAAT), $40 \mathrm{bp}$ upstream of the octamer motif (OCTA), was used to compare the binding of Oct-1 $(A)$ and Oct-2 $(B)$ in the absence and presence of VP16 as measured by protection from cleavage by DNase I. $(-$ and +1 Reactions contained combinations of E. coli-expressed Oct-1 or Oct-2 POU domain, affinity-purified HCF, and E. coli-expressed VP16 as indicated at the top of each lane. The direction and location of the sequences are indicated by arrows and brackets. (OCTA and TAAT) Probe contained wild-type octamer and (OCTA ${ }^{-}$|TAATGARAT sites; (TAAT) probe contained a wildtype (OCTA $^{-}$|TAATGARAT site and a mutant octamer motif; (OCTA) probe contained a wild-type octamer motif and a mutant $\left(\mathrm{OCTA}^{-}\right)$TAATGARAT site. Mutated sites are indicated by the XX's. The mutations were as shown in Fig. 1A. In this experiment, the sample in lane 9 was digested more extensively with DNase I than the other samples.

tion of the (OCTA ${ }^{-}$|TAATGARAT site (lane 4). The effects at the two different sites are independent of one another because the protection pattern of each site remains the same in the presence of the double point mutations (Fig. 1A) at the other site (lanes 7-12). The limits of the (OCTA ${ }^{-}$|TAATGARAT site protection in the presence of VP16 are extended compared with the protection by high concentrations of Oct-1 in the absence of VP16 (data not shown). This result indicates that VP16 is bound to the (OCTA ${ }^{-}$) TAATGARAT site, as described previously by Preston et al. (1988). Thus, it appears that Oct-1 and VP16 cooperate such that each binds more effectively over the OOCTA $^{-}$|TAATGARAT site. We refer to this effect as corecruitment.

In contrast to Oct-1, Oct-2 fails to respond to VP16, as shown in Figure 4B, because the (OCTA $^{+}$|TAATGARAT-like octamer protection pattern is not extended nor is the partial protection of the low-affinity (OCTA ${ }^{-}$)TAATGARAT site strengthened (lanes 2-4). Thus, corecruitment to the (OCTA ${ }^{-}$|TAATGARAT site is selective for VP16 and one (Oct-1), but not the other (Oct-2), of two proteins that display the same DNA-binding specificity on their own. The recruitment of Oct-1 to the (OCTA ${ }^{-}$|TAATGARAT site in vitro supports the model that the VP16-dependent activation of the (OCTA $\left.{ }^{-}\right)$TAATGARAT site in vivo involves an increase in Oct-1 occupancy of this site, as suggested by the activation of the U2 promoter shown in Figure 3 in response to the carboxy-terminally truncated VP16 protein (VP16 $\Delta$ C).

\section{Murine Oct-1 associates with VP16 less effectively than human Oct-1}

Because VP16 is not present in uninfected cells, it has been possible to determine the domains of the protein involved in VP16-induced transcriptional activation in vivo (Ace et al. 1988; Triezenberg et al. 1988a; Greaves and O'Hare 1989; Werstuck and Capone 1989a). In contrast, it has not been possible to assess the relative abilities of or the activation domain requirements for Oct-1 and Oct- 2 to respond to VP16 in vivo, because Oct-1 is ubiquitously expressed and transient overexpression of Oct-1 from the cloned cDNA in human cells does not enhance a response to VP16 (data not shown). To overcome this problem, we developed an in vivo assay for Oct-1 and Oct- 2 response to VP16 in mouse cells.

As shown in Figure 5A, the murine Oct-1 homeo domain differs from that of human Oct-1 at four positions (Goldsborough et al. 1990; Stepchenko 1992). Two of these differences (E30D and $\mathrm{M} 33 \mathrm{~L}$ ) are at positions that are important for association with VP16 (Stern et al. 1989; Lai et al. 1992; Pomerantz et al. 1992). Consistent with this observation, Oct-1 in murine cell extracts does not associate with VP16 as effectively as does Oct-1 in human cell extracts (data not shown; $H$. Schöler, pers. comm.), although such an effect could result from different levels of the stimulatory HCF protein in these extracts. To compare directly the affinity of human and murine Oct-1 for VP16, we used in vitro-translated murine and human Oct-1 in an electrophoretic mobility retardation assay for VP16-induced complex formation on the OCTA $^{-}$|TAATGARAT site in the presence of a fixed level of human HCF. Figure 5B shows that in this assay, murine Oct-1 does form a VP16-induced complex (labeled VIC; cf. lanes 2 and 3 with lanes 4 and 5), but at a significantly reduced level from that of human Oct-1 
Figure 5. Murine Oct-1 associates with VP16 less effectively than human Oct-1. $(A)$ The positions and identities of Oct-1 amino acids that differ between the human and murine Oct-1 homeo domains are indicated on an illustration of the engrailed homeo domain bound to the major groove of DNA (stippled) [adapted from Kissinger et al. (1990)]. In the nomenclature system used here, the identity of the human Oct- 1 residue is given first in single-letter code, followed by its position in the homeo domain and the identity of the differing murine Oct-1 residue. $(B)$ Electrophoretic mobility retardation analysis comparing VP16 association with murine Oct-1 and human Oct-1. Either no in vitro translation extract (lane 1) or equivalent amounts of unprogrammed (URL; lanes 2,3), or murine Oct-1 (lanes 4,5) or human Oct-1 (lanes 6,7) programmed in vitro translation extracts were incubated with an OOCTA $^{-}$|TAATGARAT probe in the absence $(-$; lanes $1,2,4,6)$ and presence $(+$; lanes $3,5,7)$ of $E$. coli-expressed VP16. All binding reactions contained partially purified human HCF. (VIC) VP16-induced complex.

B

A

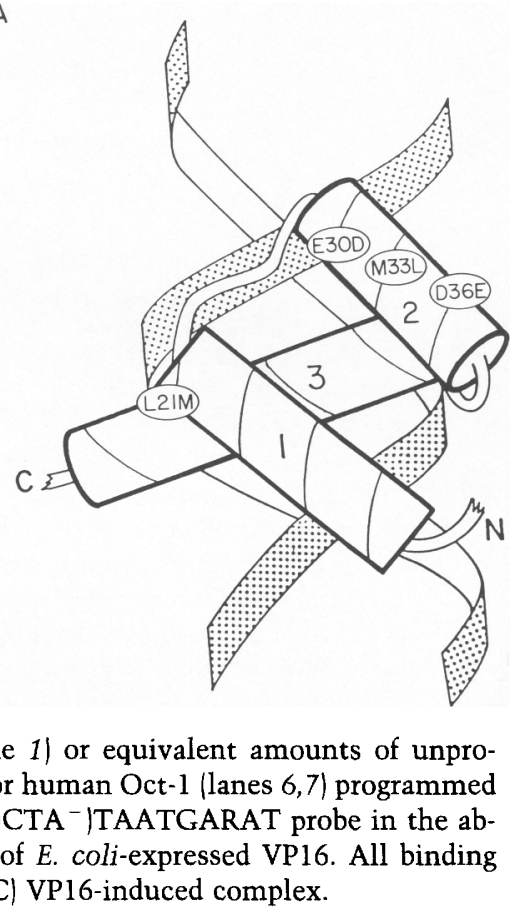

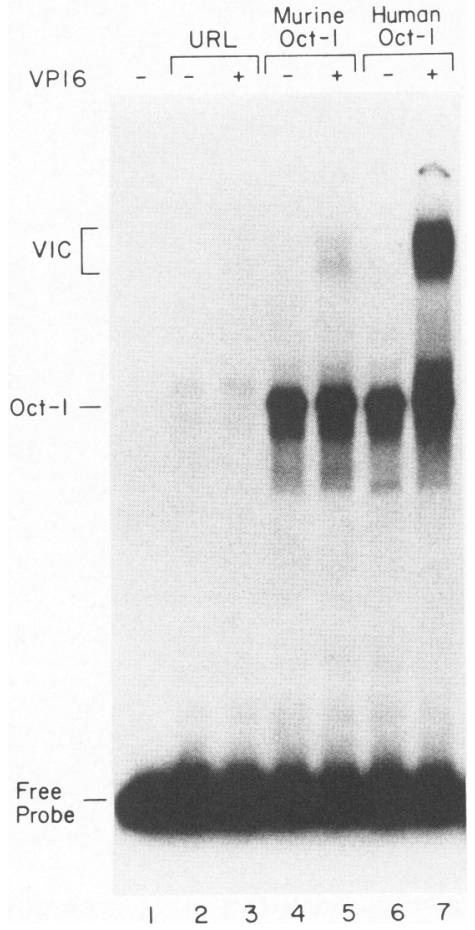

(lanes 6,7). Thus, murine Oct-1 has a lower affinity for VP16 than human Oct-1, most likely attributable to amino acid differences between the murine and human Oct-1 homeo domains.

Oct-1, but not Oct-2 can activate transcription in vivo in response to VP16

The lower affinity of murine Oct-1 for VP16 suggested that VP16 might not activate transcription as efficiently in mouse cells as in human cells, thus potentially providing an in vivo assay for the response of human Oct-1 and Oct-2 to VP16. We therefore tested the effects of VP16, human Oct-1 and Oct-2, as well as Oct-1/Oct-2 chimeras and deletion mutants on transcription from our (OCTA $^{-}$)TAATGARAT-containing $\beta$-globin promoter construct in murine NIH-3T3 cells. The structures of the Oct-related activators used in this assay are shown in Figure 6 (right). The relative activities of each activator in the presence of VP16 (Activation) and the activators' relative levels of expression as determined by electrophoretic mobility retardation analysis of transfected cell extracts (Binding) are listed alongside the structures of the activators in Figure 6. Although the levels of Oct-related activator expression varied as much as 10-fold, this variation did not affect the discrimination between Oct- 1 and Oct- 2 by VP16. The RNase protection results in Figure 6 show that the (OCTA ${ }^{-}$|TAATGARAT site fails to respond to overexpression of Oct-1 (Oct-1.1.1; lane 2) or Oct-2 (Oct-2.2.2; lane 5) in the absence of VP16. In accord with the ability of VP16 to activate transcription in another mouse cell line (Post et al. 1981; Triezenberg et al. 1988a,b) and the weak ability of murine Oct-1 to interact with VP16 (Fig. 5), the (OCTA ${ }^{-}$|TAATGARAT site is weakly active in the presence of VP16 (lane 3). Because we observe no promoter activity in the absence of VP16, on longer exposure of the autoradiograph, the activation by VP16 alone can appear quite dramatic in mouse cells. with additional human Oct-1, however, VP16 enhances the level of $\beta$-globin mRNA expression 14-fold (cf. lanes 3 and 4); as expected, this high level of activity is dependent on the wild-type (OCTA-)TAATGARAT site (lane 15). With additional human Oct-2, however, VP16 activation is not significantly enhanced (cf. lanes 3 and 6). Thus, we have succeeded in developing a suitable assay to demonstrate in vivo that the OCTA $^{-}$|TAATGARAT site is Oct- 1 but not Oct-2 responsive in the presence of VP16, probably because of selective VP16 and human Oct-1 corecruitment to this otherwise unresponsive site. This effect results in differential transcriptional activation by 

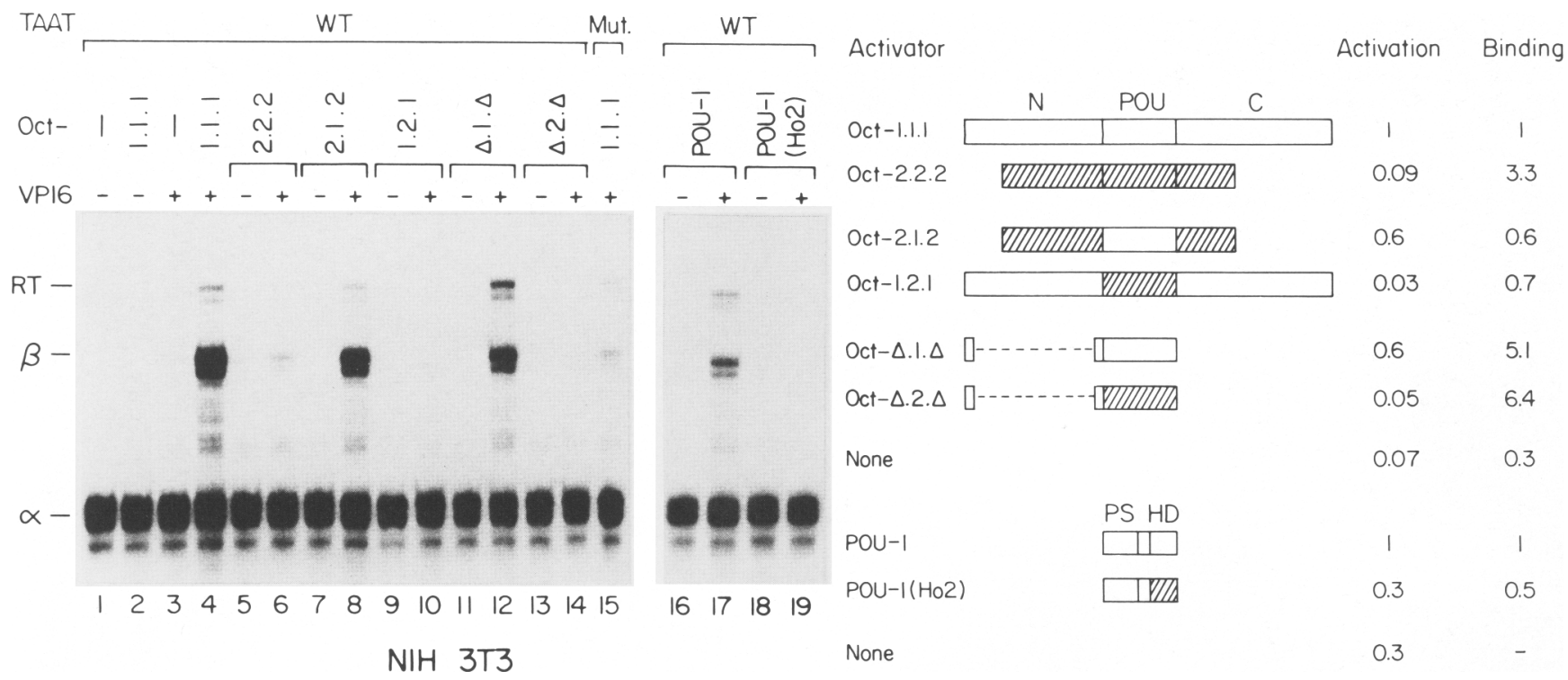

Figure 6. The Oct-1 POU domain is sufficient for VP16-induced positive control in vivo. The pU2/ $\beta$ reporter containing tandem wild-type (WT) or mutant [(Mut.) lane 15] (OCTA-)TAATGARAT (TAAT) sites was transfected into murine fibroblast NIH-3T3 cells together with expression vectors for Oct-1 or Oct-2, derivatives thereof, and/or VP16. The identity of the Oct-related activators is listed above each lane and the structure of each activator is shown diagrammatically at right. (-) No Oct-related activator was included. Lanes 16-19 are the result of a separate transfection assay. In the right-hand panel, which shows the structures of the Oct-related activators, the hatched regions are derived from Oct-2. To the right of these stuctures is shown the quantitation of the activation in the presence of VP16 (Activation) and the expression of the Oct-related activators relative to Oct-1.1.1 (top) and POU-1 (bottom), as determined by electrophoretic mobility retardation analysis (Binding) and normalized as described for reporter and effector expression, respectively, in Materials and methods.

proteins with the same inherent DNA-binding specificity.

\section{The Oct-1 POU domain is sufficient for VP16-induced positive control}

We used the human Oct-1-dependent mouse cell assay for VP16-induced positive control of transcription to determine the sequences within Oct- 1 that are required and sufficient for VP16-induced transcriptional activation. In a matched pair of Oct- 1 and Oct- 2 chimeric proteins, in which the POU domains have been exchanged |Oct-2.1.2 and Oct-1.2.1; see Fig. 6, right, Tanaka and Herr 1990), the response to VP16 segregated with the Oct-1 POU domain (Fig. 6, left, lanes 7-10), consistent with the ability of these chimeras to associate with VP16 in vitro (Stern et al. 1989). Thus, Oct-2 sequences flanking the POU domain do not interfere with VP16-induced transcriptional activation in vivo. Furthermore, Oct-1 mRNA promoter or snRNA promoter activation domains flanking the POU domain (Tanaka and Herr 1990; Tanaka et al. 1992) are not required for VP16 to activate transcription because when deleted, as in the Oct-1 POU domain construct Oct- $\Delta .1 . \Delta$ (lanes 11,12), a good response to VP16 remains.

Consistent with in vitro complex assembly between Oct-1 and VP16 (Stern et al. 1989), the Oct-1 homeo domain is apparently the key determinant for VP16-induced transcriptional positive control in vivo, because neither the Oct-2 POU domain (Oct- $\Delta .2 . \Delta$; lanes 13,14 ) nor, in a separate assay, the Oct-1 POU domain carrying the Oct-2 homeo domain (cf. lanes 16 and 17 with lanes 18 and 19 | responds to VP16. This result also shows that the Oct-1 DNA-binding domain is sufficient for VP16induced positive control, as if only the ability of Oct-1 to participate in corecruitment with VP16 is required to induce VP16 to stimulate mRNA transcription from the (OCTA $^{-}$)TAATGARAT site.

\section{Discussion}

Eukaryotic transcription factors are generally modular in structure, consisting of separable DNA-binding and transcriptional activation domains (Brent and Ptashne 1985; Ptashne 1988). Although the sequence specificity of DNA-binding domains is a major determinant for promoter selectivity in transcriptional regulation, DNAbinding alone falls short of explaining the ability of proteins with similar DNA-binding specificity to activate or repress different target promoters. Homeo domain proteins are prime examples of proteins that share similar or identical DNA-binding specificities and yet effect different patterns of gene expression. One way to achieve such differential gene regulation is through the use of promoter-selective activation domains, which can discriminate between different promoters. In this way, Oct-1 preferentially activates RNA polymerase II transcription from an snRNA promoter and Oct- 2 preferentially activates transcription from an mRNA promoter (Tanaka et al. 1992). Here, we have shown that like activation do- 
mains, DNA-binding domains also can be used to achieve differential regulation by proteins that display the same DNA-binding specificity on their own.

\section{Role of DNA-binding domains in positive control}

In eukaryotes, there are now numerous examples of DNA-binding domain mutations that affect transcriptional regulation by transcription factors without obviously affecting their DNA-binding ability, including mutations in the glucocorticoid receptor (Hollenberg and Evans 1988; Schena et al. 1989), the yeast activator HAP1 (Kim and Guarente 1989), and the muscle cellspecific transcription factors MyoD (Weintraub et al. 1991; Davis and Weintraub 1992) and myogenin (Schwarz et al. 1992); the presumptive protein association affected by these mutations has not, however, been identified. In prokaryotes, the paradigm of this type of mutation is positive control mutations in the bacteriophage $\lambda$ repressor. Such positive control mutations affect the ability of $\lambda$ repressor to stimulate transcription of its own gene without disrupting its ability to bind DNA or to act as a repressor (Guarente et al. 1982); they lie on the solvent-exposed surface of the DNA-bound $\lambda$ repressor DNA-binding domain, which consists of a helix-turnhelix motif similar in structure to the homeo domain (Hochschild et al. 1983). By replacing the Oct-1 homeo domain with the Oct- 2 homeo domain, we have shown that mutations on the surface of the Oct-1 homeo domain disrupt VP16-dependent transcriptional activation in vivo. Because of the strong parallels to $\lambda$ repressor, we refer to these mutations as positive control mutations. Their effects are better understood than those of other eukaryotic positive control mutations because both the structure of the homeo domain and the identity of the protein targeting the DNA-binding domain are known.

\section{Differential transcriptional regulation through selective corecruitment}

Previous studies have shown that by virtue of its potent acidic activation domain, VP16 causes Oct-1 to activate transcription of mRNA-type promoters in a manner more typical of Oct-2 (for review, see Herr 1992). Analysis of Oct-1 and Oct-2 transcriptional activation from the (OCTA-) ITAATGARAT site has shown that VP16 and Oct-1 corecruitment can result in activation of a promoter that fails to respond to Oct-2. Corecruitment by DNA-binding transcriptional regulators has also been observed with the yeast transcription factors MCM1 and $\alpha 1$ (Bender and Sprague 1987) and al and $\alpha 2$ (Dranginis 1990). Here, corecruitment is used to bring Oct-1 but not Oct-2 to the /OCTA-|TAATGARAT site, thereby achieving differential regulation of transcription by proteins that display the same DNA-binding specificity on their own. Thus, Oct- 2 can activate octamer motif-containing mRNA promoters through the use of promoterselective activation domains, and Oct-1 can activate TAATGARAT-containing mRNA promoters through selective association with VP16. In this same manner,
VP16 effectively expands the repertoire of Oct-1-responsive sites without affecting the number of Oct-2-responsive sites.

The corecruitment by the ubiquitous cellular protein Oct- 1 and the viral protein VP16 to the (OCTA ${ }^{-}$|TAATGARAT site leads to promoter activation by Oct- 1 that is cell type specific in the sense that only HSV-infected cells or cells expressing VP16 show transcriptional stimulation of $\left(\mathrm{OCTA}^{-} \mid \mathrm{TAATGARAT}\right.$. Such promoter selectivity by corecruitment between a broadly expressed homeo domain protein and a more narrowly expressed cofactor may also explain cell-specific transcriptional regulation by more broadly expressed homeo domain proteins during development as in Drosophila.

We have shown that the Oct-1 DNA-binding domain, the POU domain, is sufficient both to achieve VP16 corecruitment to the OOCTA $^{-}$|TAATGARAT site in vitro and to effect VP16-induced positive control in vivo. Thus, when activating transcription in association with VP16, the Oct-1 POU domain can be viewed as possessing inseparable DNA-binding and activation surfaces. The activation surface, or what might functionally be referred to as the activation domain, activates transcription by recruiting VP16 with its potent acidic activation domain to the cis-regulatory target. Whereas differential promoter activation by Oct- 1 and Oct- 2 through promoter-selective activation domains probably involves "long-range" interactions with the promoter-proximal initiation complex, the second mechanism for differential activation shown here probably involves "shortrange" interactions with the Oct-1 DNA-binding domain in which Oct-1 and VP16 come together to augment each other's occupancy of the (OCTA-)TAATGARAT site.

\section{Implications of Oct-1 homeo domain variability in mice and humans}

The primary structure of the Oct-1 homeo domain is conserved among Xenopus (Smith and Old 1990), chickens (Petryniak et al. 1990), and humans (Sturm et al. 1988--members of three separate vertebrate classes. During mammalian evolution, however, the homeo domain has varied. This variation can be seen when the human and rodent Oct-1 homeo domains are compared. As illustrated in Figure 5, the murine Oct-1 homeo domain contains four differences with respect to its human counterpart (Goldsborough et al. 1990; Stepchenko 1992). Even within rodents the Oct-1 homeo domain varies because a partial rat Oct-1 homeo domain sequence shows that this homeo domain contains the same four murine differences and, in addition, a pair of differences at the amino-terminal end of helix 1 (Lillycrop and Latchman 1991). Curiously, two of the rodent-specific differences in helix 2 (M33L and D36E) are identical to the residues found at these positions in murine (Hatzopoulous et al. 1990) and human (Clerc et al. 1988; Ko et al. 1988; Müller et al. 1988; Scheidereit et al. 1988) Oct2; perhaps the changes in the murine Oct- 1 homeo domain arose in part by gene conversion with the Oct-2- 
coding sequences. The methionine to leucine exchange at position $33(\mathrm{M} 33 \mathrm{~L})$ is partially responsible for the poor association of VP16 with Oct-2 (Stern et al. 1989; Lai et al. 1992; Pomerantz et al. 1992), whereas the glutamic acid residue at position 30 of the human Oct- 1 homeo domain is also important for association with VP16 (Pomerantz et al. 1992). It is therefore likely that the murine Oct-1 M33L and E30D glutamate-to-aspartate changes are responsible for the weakened association of murine Oct-1 with VP16.

The weaker association of murine Oct-1 and VP16 led to the development of an in vivo assay for the involvement of Oct-1 in the activation of transcription by VP16. The success of this assay was unexpected because the original finding that a virion component, which was later identified as VP16 (Campbell et al. 1984), trans-activates the HSV immediate early promoters was made in mouse $\mathrm{L}$ cells (Post et al. 1981). Our studies show that VP16 does activate transcription in murine cells (see Fig. 6); and because the background transcription level in the absence of VP16 is undetectable, the fold activation by VP16 in murine cells appears very large. Only when contrasted with the enhanced level of VP16 activation in the presence of transiently expressed human Oct-1 does the VP16 response with endogenous murine Oct-1 appear weak.

The variability exhibited by rodent Oct-1 homeo domains has implications for the involvement of the Oct-1 homeo domain in the regulation of cellular gene transcription through protein-protein interactions with its solvent-exposed surface. An attractive hypothesis to explain how Oct-1 may mediate activation of cellular mRNA-type promoters has been that cellular cofactors exist that, like VP16, interact with the Oct-1 homeo domain to regulate transcription. But the evolutionary diversity of the Oct-1 surface that directs association with VP16, together with its apparent deleterious effects on VP16-induced positive control, suggests that the variation in the murine Oct-1 homeo domain would have an impact on the association of Oct-1 and such a cellular cofactor unless perhaps (1) the cellular cofactor interacts with a different-unaffected-surface of the Oct-1 homeo domain or (2) the cellular cofactor has effectively evolved to compensate for the changes in the rodent Oct-1 homeo domains. Alternatively, a weakened cofactor/Oct-1 interaction is still sufficient for activity or the activity is no longer required, perhaps because a separate mechanism evolved in rodents that circumvents the requirement for positive control by the Oct-1 homeo domain and therefore for an Oct-1 homeo domain cofactor.

In addition to its evolutionary implications, the poorer ability of mouse Oct-1 to associate with VP16 compared with human Oct-1 has implications for the use of rodents as animal models for HSV infection. The difference in an important virus-host cell interaction for activation of the HSV immediate early genes suggests that the course of HSV infection in mice or rats, particularly the balance between latent and lytic infection, may differ from that in humans. It may be possible to evaluate the influence of human Oct-1 on the pathology of HSV infection by using mice expressing human Oct-1.

\section{Materials and methods}

Construction of reporter plasmids

The pU2/ $\beta$ plasmid contains a U2 promoter-driven transcription unit, the HindIII fragment from pU2/ - 198 (Hernandez and Lucito 1988), inserted into the SstI site of the $\beta$-globin promoter-containing plasmid $\mathrm{p} \beta \Delta^{36}$ (Tanaka and Herr 1990). Sixtandem-copy cis-regulatory elements were generated by successive ligation of the individual 24-bp double-stranded DNA elements made with complementary synthetic oligonucleotides and then inserted into the SphI site in the plasmid $\mathrm{pBe}^{-}$as described (Ondek et al. 1988). To transfer these tandem-copy segments to the $\mathrm{pU} 2 / \beta$ plasmid, they were excised from the $\mathrm{p} \beta \mathrm{e}^{-}$derivative by PstI-HindIII digestion and inserted bluntended into the SmaI site of the pUC119 polylinker sequence in $\mathrm{pU} 2 / \beta$ between the $\beta$-globin and U2 promoters. The four new six-tandem-copy elements described here (Fig. 1A) are referred to as $\mathrm{pU} 2 / \beta 6 \times \mathrm{H} 2 \mathrm{~B} / \mathrm{OCTA}$ for the human $\mathrm{H} 2 \mathrm{~B}$-derived octamer element (LaBella et al. 1988) and pU2/ $66 \times \mathrm{H} 2 \mathrm{~B} /$ OCTAdpm 1 for the corresponding mutant site, and $\mathrm{pU} 2 / \beta 6 \times$ ICP4/TAAT-1 for the /OCTA ${ }^{-}$/TAATGARAT site (Preston et al. 1988) and $\mathrm{pU} 2 / \beta 6 \times$ ICP4/TAAT- $1 \mathrm{dpm} 1$ for the corresponding mutant site. The six-tandem octa ${ }^{+} \mathrm{sph}^{+}$and octa ${ }^{-} \mathrm{sph}^{-}$elements were transferred from $\mathrm{p} \beta 6 \times \mathrm{B} 20$ and $\mathrm{p} \beta 6 \times \mathrm{B} 20 \mathrm{dpm} 8$, respectively (Tanaka et al. 1988). Except for the wild-type and mutant (OCTA ${ }^{-}$|TAATGARAT elements, each site was in the plus $(+)$ orientation, meaning that the sequence in Figure $1 \mathrm{~A}$ reads $5^{\prime}$ to $3^{\prime}$ in a clockwise direction in Figure $1 \mathrm{~B}$. The (OCTA ${ }^{-}$|TAATGARAT elements, which function in either orientation, were placed in the opposite minus $(-)$ orientation because this direction provides the best similarity to the octamer motif as described in Baumruker et al. (1988). The internal reference plasmid $\mathrm{p} \alpha 4 \times(\mathrm{A}+\mathrm{C})$ containing the human $\alpha$-globin transcription unit is described in Tanaka and Herr (1990).

\section{Effector plasmids}

Expression constructs for wild-type Oct-1 (pCGoct-1.1.1) and Oct-2 (pCGoct-2.2.2), the Oct-1/Oct-2 chimeras pCGoct-1.2.1 and pCGoct-2.1.2, and the Oct-1 and Oct-2 deletion constructs pCGoct $-\Delta .1 . \Delta$ and pCGoct- $\Delta .2 . \Delta$, are described in Tanaka and Herr (1990). POU-1 (pCGoct-1-POU) and POU-1(Ho2) [pCGoct1-POU(Ho2)] are described in Lai et al. (1992). The expression constructs for wild-type VP16 (pCGNVP16), carboxy-terminally truncated VP16 $\mathrm{C}$ (pCGNVP16 $\mathrm{C}$; containing residues 5-410), and the in 14 insertion mutant (Ace et al. 1988) in the VP16 6 C background (pCGNVP16 $\Delta$ C-in14) contain the VP16-coding sequences inserted between the pCG (Tanaka and Herr 1990) XbaI and BamHI sites (A. Wilson and W. Herr, unpubl.).

\section{In vivo transcription assays}

HeLa cells were seeded at $5 \times 10^{5}$ cells per 10 -cm plate and transfected after $24 \mathrm{hr}$ by calcium phosphate coprecipitation as described by Tanaka et al. (1988). Each reporter construct (4 $\mu \mathrm{g}$ ) was transfected along with the internal reference plasmid $\mathrm{p} \alpha 4 \times(\mathrm{A}+\mathrm{C})(68 \mathrm{ng})$. In those cells where wild-type or mutant VP16 proteins were coexpressed, $1 \mu \mathrm{g}$ of pCGNVP16 or a derivative was cotransfected. NS- 1 cells, a nonsecreting mouse myeloma cell line, were transfected by the DEAE-dextran and chloroquine method as described by Ondek et al. (1987). Cells $\left(1 \times 10^{7}\right)$ on $10-\mathrm{cm}$ plates were transfected with $4 \mu \mathrm{g}$ of $\mathrm{pU} 2 / \beta$ reporter plasmid and $1 \mu \mathrm{g}$ of $\alpha \alpha \times(\mathrm{A}+\mathrm{C})$. Murine NIH-3T3 
fibroblasts were seeded at $3.5 \times 10^{5}$ cells per 10 -cm plate $24 \mathrm{hr}$ in advance and transfected in the manner described for HeLa cells except that $0.46 \mu \mathrm{g}$ of each plasmid expressing Oct-1, Oct2 , or Oct- 1 and Oct- 2 variants and $0.54 \mu \mathrm{g}$ of pCGNVP16 were cotransfected where appropriate.

To measure expression of Oct-1, Oct-2, and VP16-related proteins in HeLa or NIH-3T3 cells, cell extracts were prepared from one-tenth of the harvested cells and assayed by mobility retardation analysis as described (Tanaka et al. 1992) using a singlecopy $\left(\mathrm{OCTA}^{-}\right)$TAATGARAT probe. Endogenous HCF is not effectively extracted under the experimental conditions described in Tanaka et al. (1992); therefore, to measure VP16 expression, the binding reactions were supplemented with partially purified HCF (see below). Expression of the VP16-related proteins was also assayed by performance of an alkaline phophatase immunoblot analysis (as described in Harlow and Lane 1988) with the VP16-specific monoclonal antibody LP1 (McLean et al. 1982) as the primary antibody.

To measure reporter gene expression, cytoplasmic RNA was collected by the NP-40/lysis method and analyzed by RNase protection (Ondek et al. 1987). The probes used for RNA hybridization were antisense transcripts to $\alpha$-globin mRNA $(\alpha 98$; Gilman 1988), $\beta$-globin mRNA ( $\beta 134 ; \mathrm{W}$. Thomann and W. Herr, unpubl.), or the U2 promoter-driven snRNA transcription construct (Probe A; Hernandez and Lucito 1988). Unprotected RNA was digested by RNases $A$ and $T_{1}$, and the protected fragments were visualized after electrophoresis through a $6 \%$ denaturing gel. Levels of reporter and effector gene expression were quantitated with a Fuji BAS2000 PhosphorImager and normalized to the level of expression of the internal reference $\alpha$-globin RNA. For the NIH-3T3 cell assay shown in Figure 6, the internal $\alpha$-globin reference varied from $23 \%$ to $100 \%$ of the highest level before normalization.

\section{HCF purification}

HCF activity was purified from HeLa cells by protein affinity with VP16 (Kristie and Sharp 1990; Xiao and Capone 1990; Stern and Herr 1991). Protein A-VP16 fusion protein prepared from 2 liters of $E$. coli and purified over IgG-Sepharose as described previously (Stern and Herr 1991) was rebound to $500 \mu 1$ of IgG-Sepharose in a 1-ml disposable pipette. After equilibration with buffer D, $5 \mathrm{ml}$ of nuclear extract (Dignam et al. 1983) was passed over the protein A-VP16 column. The column was subsequently washed with $5 \mathrm{ml}$ of TST buffer and eluted with 1 $\mathrm{M} \mathrm{KCl}$ as described previously for the HCF microprecipitation assay (Xiao and Capone 1990; Stern and Herr 1991). Peak activity fractions were screened by mobility retardation assay with $E$. coli-expressed Oct-1 POU domain and protein A-VP16 fusion protein, pooled, and dialyzed against $0.1 \mathrm{M} \mathrm{KCl}, 50 \mathrm{mM}$ Tris $(\mathrm{pH}$ $7.6)$ and $20 \%$ sucrose. This HCF preparation was devoid of detectable Oct-1 as determined by mobility retardation analysis.

\section{DNase I protection analysis}

To generate the probes used for DNase I protection, one copy of a flush-end XhoI fragment with the wild-type or mutant $\mathrm{H} 2 \mathrm{~B}$ octamer sequence (Fig. 1A) was cloned into the HindIII site of the pUC119 polylinker and an analogous copy of the wild-type or mutant (OCTA-)TAATGARAT sequence (Fig. 1A) was cloned into the HincIl site of the pUC119 polylinker. The octamer- and (OCTA ${ }^{-}$)TAATGARAT-containing vector was then digested with EcoRI and the ends were filled in by the Klenow fragment and radiolabeled dATP and dTTP, followed by digestion with BstNI and polyacrylamide gel purification. For each DNase I protection, 20,000 cpm of probe was used. Protein-
DNA-binding reactions were performed in 12.5- $\mu$ l reactions containing $8 \mathrm{~mm} \mathrm{Na}-\mathrm{HEPES}$ ( $\mathrm{pH} 7.9$ ), $60 \mathrm{~mm} \mathrm{NaCl}, 4 \mathrm{~mm}$ spermidine, $2 \mathrm{~mm}$ EDTA, $0.2 \mathrm{~mm}$ DTT, $0.03 \% \mathrm{NP}-40,0.1 \mathrm{mg} / \mathrm{ml}$ of BSA, $0.01 \mathrm{mg} / \mathrm{ml}$ of unsonicated poly[d(I-C)] (Pharmacia), and $2 \%$ polyvinyl alcohol. E. coli-expressed Oct-1 and Oct-2 POU domain protein $(\sim 0.24 \mathrm{ng}$ per reaction) purified to near homogeneity ( $>90 \%$ ) by DNA affinity (Kadonaga and Tjian 1986) was used. Where appropriate, $1 \mu$ l of partially purified HCF and $\sim 25$ ng of protein A-VP16 were used.

For DNase I protection analysis, the protein-DNA-binding reactions were incubated at $37^{\circ} \mathrm{C}$ for $30 \mathrm{~min}$ and then on ice until treatment. Before the addition of DNase I, $50 \mu \mathrm{l}$ of ice-cold $10 \mathrm{mM} \mathrm{MgCl} / 2 / 5 \mathrm{mM} \mathrm{CaCl}_{2}$ was added to the reactions, which were then incubated on ice for $1 \mathrm{~min}$. DNase I (100 $\mathrm{ng}$ ) was then added; and after a 1-min incubation on ice, the cleavage reactions were stopped by the addition of $90 \mu \mathrm{l}$ of $20 \mathrm{mM}$ EDTA $(\mathrm{pH}$ $81,1 \%$ SDS, $0.2 \mathrm{M} \mathrm{NaCl}$, and $100 \mu \mathrm{g}$ of yeast RNA. Samples were phenol extracted once, ethanol precipitated, and analyzed by $6 \%$ denaturing polyacrylamide gel electrophoresis.

\section{Mobility retardation analysis}

In vitro-translated murine Oct-1 and human Oct- 1 were generated by the use of plasmids oct-1 clone 8 (gift of $\mathrm{H}$. Schöler; Schöler et al. 1990) and pBSoct- $1^{+}$(Sturm et al. 1988), respectively. Each coding sequence was rendered transcribable by SP6 polymerase through polymerase chain reaction (PCR) amplification with an Oct-1-related primer containing the SP6 promoter and a primer complementary to $\mathrm{pUC1} 19$ polylinker sequence as described previously (Aurora and Herr 1992). Oct-1encoding SP6 transcripts were then translated in vitro by use of a rabbit reticulocyte lysate. Levels of the $\left[{ }^{35} S\right]$ methionine- labeled in vitro translation products were measured after fractionation of the products on a polyacrylamide gel. Translation extracts were equilibrated for Oct-1 expression with unprogrammed reticulocyte lysate, and $3 \mu \mathrm{l}$ was used in mobility retardation analysis as follows. Binding reactions were carried out in 10- $\mu$ l volumes in $4 \mathrm{~mm}$ Tris- $\mathrm{HCl}$ (pH 7.9), $20 \mathrm{mM} \mathrm{KCl}, 1.4$ mM DTT, $0.4 \mathrm{~mm}$ EDTA, $0.04 \%$ NP-40, $0.4 \%$ glycerol, and $0.8 \%$ Ficoll with $1 \mathrm{ng}$ of denatured salmon sperm DNA, $1 \mu \mathrm{g}$ of poly[d(I-C)], $0.5 \mu \mathrm{l}$ of partially purified HCF. Where appropriate, $40 \mathrm{ng}$ of glutathion $S$-transferase (GST)-VP16 $1 \mathrm{C}$ fusion protein was included in the reactions. The HCF and GST-VP16 $\triangle \mathrm{C}$ preparations were a gift of A. Wilson (Cold Spring Harbor Laboratory). Binding was carried out at $30^{\circ} \mathrm{C}$ for $30 \mathrm{~min}$ before samples were loaded on a 4\% 1:39 bis/acrylamide gel prepared in 20 $\mathrm{mM}$ Tris, $0.2 \mathrm{M}$ glycine, and $1 \mathrm{mM}$ EDTA and subjected to electrophoresis.

\section{Acknowledgments}

We gratefully acknowledge A. Wilson for providing essential reagents and helpful discussion, $W$. Thomann for the $\beta 143$ probe, J.-S. Lai for the POU-1 and POU-1 (Ho2) expression constructs, C. Preston for the plasmid pMC20 containing the IOCTA $^{-}$|TAATGARAT sequence used here, A. Minson for providing LP1 antibody, and $\mathrm{H}$. Schöler for mouse oct-1 clone 8 and for communicating unpublished results. We also thank G. Das for communicating unpublished results. We thank S. Bell, M. Gilman, N. Hernandez, J.-S. Lai, and A. Wilson for critical review of the manuscript. In addition, we thank J. Duffy, M. Ockler, and P. Renna for artwork preparation and photography. These studies were supported by U.S. Public Health Service grant CA-13106 from the National Cancer Institute.

The publication costs of this article were defrayed in part by 
payment of page charges. This article must therefore be hereby marked "advertisement" in accordance with 18 USC section 1734 solely to indicate this fact.

\section{References}

Ace, C.I., M.A. Dalrymple, F.H. Ramsay, V.G. Preston, and C.M. Preston. 1988. Mutational analysis of the herpes simplex virus type 1 trans-inducing factor Vmw65. J. Gen. Virol. 69: 2595-2605.

apRhys, C.M., D.M. Ciufo, E.A. O'Neil, T.J. Kelly, and G.S. Hayward. 1989. Overlapping octamer and TAATGARAT motifs in the VF65-response elements in herpes simplex virus immediate-early promoters represent independent binding sites for the cellular Nuclear Factor III. J. Virol. 63: 27982812.

Aurora, R. and W. Herr. 1992. Segments of the POU domain influence one another's DNA-binding specificity. Mol. Cell. Biol. 12: 455-467.

Baumruker, T., R. Sturm, and W. Herr. 1988. OBP100 binds remarkably degenerate octamer motifs through specific interactions with flanking sequences. Genes \& Dev. 2: 14001413.

Bender, A. and G.F. Sprague Jr. 1987. Mat $\alpha 1$ protein, a yeast transcription activator, binds synergistically with a second protein to a set of cell-type-specific genes. Cell 50: 681-691.

Brent, R. and M. Ptashne. 1985. A eukaryotic transcriptional activator bearing the DNA specificity of a prokaryotic repressor. Cell 43: 729-736.

Campbell, M.E.M., J.W. Palfreyman, and C.M. Preston. 1984. Identification of herpes simplex virus DNA sequences which encode a trans-acting polypeptide responsible for stimulation of immediate early transcription. I. Mol. Biol. 180: 1-19.

Clerc, R.G., L.M. Corcoran, J.H. LeBowitz, D. Baltimore, and P.A. Sharp. 1988. The B-cell-specific Oct-2 protein contains POU box- and homeo box-type domains. Genes \& Dev. 2: $1570-1581$.

Davis, R.L. and H. Weintraub. 1992. Acquisition of myogenic specificity by replacement of three amino acid residues from MyoD into E12. Science 256: 1027-1030.

Dignam, J.D., R.M. Lebovitz, and R.G. Roeder. 1983. Accurate transcription by RNA polymerase II in a soluble extract from isolated mammalian nuclei. Nucleic Acids Res. 11: 14751489.

Dranginis, A.M. 1990. Binding of yeast al and $\alpha 2$ as a heterodimer to the operator DNA of a haploid-specific gene. Nature 347: 682-685.

Gerster, T. and R.G. Roeder. 1988. A herpesvirus trans-activating protein interacts with transcription factor OTF-1 and other cellular proteins. Proc. Nat1. Acad. Sci. 85: 6347-6351.

Gilman, M.Z. 1988. The c-fos serum response element responds to protein kinase $\mathrm{C}$-dependent and -independent signals but not to cyclic AMP. Genes \& Dev. 2: 394-402.

Goding, C. and P. O'Hare. 1989. Herpes simplex virus Vmw65octamer-binding protein interaction: A paradigm for combinatorial control of transcription. Virology 173: 363-367.

Goldsborough, A., A. Ashworth, and Keith Willison. 1990. Cloning and sequencing of POU-boxes expressed in mouse testis. Nucleic Acids Res. 18: 1634.

Greaves, R. and P. O'Hare. 1989. Separation of requirements for protein-DNA complex assembly from those for functional activity in the herpes simplex virus regulatory protein Vmw65. I. Virol. 63: 1641-1650.

Guarente, L., A. Nye, A. Hochschild, and M. Ptashne. 1982.
Mutant $\lambda$ phage repressor with a specific defect in its positive control function. Proc. Natl. Acad. Sci. 79: 2236-2239.

Harlow, E. and D. Lane. 1988. Antibodies: A laboratory manual. pp. 471-510. Cold Spring Harbor Laboratory, Cold Spring Harbor, New York.

Hatzopoulos, A.K., A.S. Stoykova, J.R. Erselius, M. Goulding, T. Neuman, and P. Gruss. 1990. Structure and expression of the mouse Oct-2a and Oct-2b, two differentially spliced products of the same gene. Development 109: 349-362.

Hayashi, S. and M.P. Scott. 1990. What determines the specificity of action of Drosophila homeo domain proteins? Cell 63: $883-894$.

Hernandez, N. and R. Lucito. 1988. Elements required for transcription initiation of the human U2 snRNA gene coincide with elements required for snRNA 3 ' end formation. EMBO J. 7: 3125-3134

Herr, W. 1992. Oct-1 and Oct-2: Differential transcriptional regulation by proteins that bind to the same DNA sequence. In Transcriptional regulation (ed. S. McKnight and K. Yamamotol, Cold Spring Harbor Laboratory Press, Cold Spring Harbor, New York. (In press.)

Hochschild, A., N. Irwin, and M. Ptashne. 1983. Repressor structure and the mechanism of positive control. Cell 32: 319-325.

Hollenberg, S.M. and R.M. Evans. 1988. Multiple and cooperative trans-activation domains of the human glucocorticoid receptor. Cell 55: 899-906.

Kadonaga, J.T. and R. Tjian. 1986. Affinity purification of sequence-specific DNA-binding proteins. Proc. Natl. Acad. Sci. 83: 5889-5893.

Katan, M., A. Haigh, C.P. Verrijzer, P.C. van der Vliet, and P. O'Hare. 1990. Characterization of a cellular factor which interacts functionally with Oct- 1 in the assembly of a multicomponent transcription complex. Nucleic Acids Res. 18: $6871-6880$.

Kemler, I., E. Bucher, K. Seipel, M.M. Müller-Immerglück, and W. Schaffner. 1991. Promoters with the octamer DNA motif (ATGCAAAT) can be ubiquitous or cell type-specific depending on binding affinity of the octamer site and Octfactor concentration. Nucleic Acids Res. 19: 237-242.

Kim, K.S. and L. Guarente. 1989. Mutations that alter transcriptional activation but not DNA-binding in the zinc finger of yeast activator HAPl. Nature 342: 200-203.

Kissinger, C.R., B. Liu, E. Martin-Bianco, T.B. Kornberg, and C.O. Pabo. 1990. Crystal structure of an engrailed homeo domain-DNA complex at $2.8 \AA$ resolution: A framework for understanding homeo domain-DNA interactions. Cell 63: 579-590.

Ko, H.-S., P. Fast, W. McBride, and L.M. Staudt. 1988. A human protein specific for the immunoglobulin octamer DNA motif contains a functional homeobox domain. Cell 55: 135144.

Kristie, T.M. and P.A. Sharp. 1990. Interactions of the Oct-1 POU subdomains with specific DNA sequences and the HSV $\alpha$-trans-activator protein. Genes \& Dev. 4: 2383-2396.

Kristie, T.M., J.H. LeBowitz, and P.A. Sharp. 1989. The octamerbinding proteins form multi-protein-DNA complexes with the HSV $\alpha$ TIF regulatory protein. EMBO J. 8: 4229-4238.

LaBella, F., H.L. Sive, R.G. Roeder, and N. Heintz. 1988. Cellcycle regulation of a human histone $\mathrm{H} 2 \mathrm{~b}$ gene is mediated by the H2b subtype-specific consensus element. Genes \& Dev. 2: 32-39.

Lai, J.-S., M.A. Cleary, and W. Herr. 1992. A single amino acid exchange transfers VP16-induced positive control from the Oct-1 to the Oct-2 homeo domain. Genes \& Dev. 6: 20582065. 
Lillycrop, K.A. and D.S. Latchman. 1991. Cloning and sequencing of the rat Oct-1 POU box. Nucleic Acids Res. 19: 3744.

McKnight, J.L.C., T.M. Kristie, and B. Roizman. 1987. Binding of the virion protein mediating $\alpha$ gene induction in herpes simplex virus 1 -infected cells to its cis site requires cellular proteins. Proc. Natl. Acad. Sci. 84: 7061-7065.

McLean, C., A. Buckmaster, D. Hancock, A. Buchan, A. Fuller and T. Minson. 1982. Monoclonal antibodies to the three nonglycosylated antigens of herpes simplex virus type $2 . J$. Gen. Virol. 63: 297-305.

Müller, M.M., S. Ruppert, W. Schaffner, and P. Matthias. 1988. A cloned octamer transcription factor stimulates transcription from lymphoid-specific promoters in non-B cell. Nature 336: 544-551.

O'Hare, P. and C.R. Goding. 1988. Herpes simplex virus regulatory elements and the immunoglobulin octamer domain bind a common factor and are both targets for virion transactivation. Cell 52: 435-445.

Ondek, B., A. Shepard, and W. Herr. 1987. Discrete elements within the SV40 enhancer region display different cell specific enhancer activities. EMBO I. 6: 1017-1025.

Ondek, B., L. Gloss, and W. Herr. 1988. The SV40 enhancer contains two distinct levels of organization. Nature 333: 40 45.

Petryniak, B., L.M. Staudt, C.E. Postema, W.T. McCormack, and C.B. Thompson. 1990. Characterization of the chicken octamer-binding proteins demonstrates that POU domaincontaining homeobox transcription factors have been highly conserved during vertebrate evolution. Proc. Natl. Acad. Sci. 87: 1099-1103.

Pomerantz, J.L., T.M. Kristie, and P.A. Sharp. 1992. Recognition of the surface of a homeodomain protein. Genes \& Dev. 6: $2047-2057$.

Post, L.E., S. Mackem, and B. Roizman. 1981. Regulation of a genes of herpes simplex virus: Expression of chimeric genes produced by fusion of thymidine kinase with a gene promoters. Cell 24: 555-565.

Preston, C.M., M.C. Frame, and M.E.M. Campbell. 1988. A complex formed between cell components and an HSV structural polypeptide binds to a viral immediate early gene regulatory DNA sequence. Cell 52: 425-434.

Ptashne, M. 1988. How eucaryotic transcriptional activators work. Nature 335: 683-689.

Scheidereit, C., J.A. Cromlish, T. Gerster, K. Kawakami, C.-G. Balmaceda, R.A. Currie, and R.G. Roeder. 1988. A human lymphoid-specific transcription factor that activates immunoglobulin genes is a homeobox protein. Nature 336: 551557.

Schena, M. L.P. Freedman, and K.R. Yamamoto. 1989. Mutations in the glucocorticoid receptor zinc finger region that distinguish interdigitated DNA-binding and transcriptional enhancement activities. Genes \& Dev. 3: 1590-1601.

Schöler, H.R., S. Ruppert, N. Suzuki, K. Chowdhury, and P. Gruss. 1990. New type of POU domain in germ line-specific protein Oct-4. Nature 344: 435-439.

Schwarz, J.J., T. Chakraborty, J. Martin, J. Zhou, and E.N. Olson. 1992. The basic region of myogenin cooperates with two transcription activation domains to induce muscle-specific transcription. Mol. Cell. Biol. 12: 266-275.

Smith, D.P. and R.W. Old. 1990. Nucleotide sequence of Xenopus laevis Oct-1 cDNA. Nucleic Acids Res. 18: 369.

Staudt, L.M., H. Singh, R. Sen, T. Wirth, P.A. Sharp, and D. Baltimore. 1986. A lymphoid-specific protein binding to the octamer motif of immunoglobulin genes. Nature 323: 640 643.

Stepchenko, A.G. 1992. The nucleotide sequence of mouse
Oct-1 cDNA. Nucleic Acids Res. 20: 1419.

Stern, S. and W. Herr. 1991. The herpes simplex virus transactivator VP16 recognizes the Oct-1 homeo domain: Evidence for a homeo domain recognition subdomain. Genes \& Dev. 5: 2555-2566.

Stern, S., M. Tanaka, and W. Herr. 1989. The Oct-1 homeo domain directs formation of a multiprotein-DNA complex with the HSV trans-activator VP16. Nature 341: 624-630.

Sturm, R.A., G. Das, and W. Herr. 1988. The ubiquitous oc tamer-binding protein Oct-1 contains a POU domain with a homeo box subdomain. Genes \& Dev. 2: 1582-1599.

Tanaka, M. and W. Herr. 1990. Differential transcriptional activation by Oct-1 and Oct-2: Interdependent activation domains induce Oct-2 phosphorylation. Cell 60:375-386.

Tanaka, M., U. Grossniklaus, W. Herr, and N. Hernandez. 1988. Activation of the U2 snRNA promoter by the octamer motif defines a new class of RNA polymerase II enhancer elements. Genes \& Dev. 2: 1764-1778.

Tanaka, M., J.-S. Lai, and W. Herr. 1992. Promoter-selective activation domains in Oct- 1 and Oct- 2 direct differential activation of an snRNA and mRNA promoter. Cell 68: 755767.

Thompson, C.C. and S.L. McKnight. 1992. Anatomy of an enhancer. Trends Genet. 8: 232-236.

Triezenberg, S.J., R.C. Kingsbury, and S.L. McKnight. 1988a Functional dissection of VP16, the trans-activator of herpes simplex virus immediate early gene expression. Genes \& Dev. 2: 718-729.

Triezenberg, S.J., K.L. LaMarco, and S.L. McKnight. 1988b. Evidence of DNA: Protein interactions that mediate HSV-1 immediate early gene activation by VP16. Genes \& Dev. 2: 730-742.

Weintraub, H., V.J. Dwarki, I. Verma, R. Davis, S. Hollenberg, L. Snider, A. Lassar, and S.J. Tapscott. 1991. Muscle-specific transcriptional activation by MyoD. Genes \& Dev. 5: 13771386.

Werstuck, G. and J.P. Capone. 1989a. Mutational analysis of the herpes simplex virus trans-inducing factor Vmw65. Gene 75: 213-224.

- $1989 \mathrm{~b}$. Identification of a domain of the herpes simplex virus trans-activator Vmw65 required for protein-DNA complex formation through the use of protein A fusion proteins. J. Virol. 63: 5509-5513.

Xiao, P. and J.P. Capone. 1990. A cellular factor binds to the herpes simplex virus type 1 trans-activator Vmw65 and is required for Vmw65-dependent protein-DNA complex assembly with Oct-1. Mol. Cell. Biol. 10: 4974-4977. 